\title{
INQUIRY-BASED LEARNING: AN EFFECTIVE APPROACH TO TEACHING SCIENCE AIMING TO DEVELOP STUDENTS' COMPETENCIES
}

\author{
Linh Thi Ngoc Bui ${ }^{+}$, \\ Vu Thuan Khuu
}

\section{Article History}

Received: December 15, 2019

Accepted: February 05, 2020

Published: March 30, 2020

\section{Keywords}

Inquiry-based learning, competency-based learning, science, 5Es instructional model

\author{
Quy Nhon University, Vietnam \\ +Corresponding author •Email: buithingoclinh@qnu.edu.vn
}

\section{INTRODUCTION}

The technological revolution 4.0 and globalisation have challenged Vietnam to educate qualified labour force to go forwards. In response to this social demand, the Ministry of Education and Training (MOET) decided to launch an innovative curriculum (2018) which is competency-based from the academic year of 2021-2020. Accordingly, teaching and learning aim to develop students' general as well as discipline-specified competencies. The curriculum is integrative in Lower secondary education (basic period) while specific in Upper secondary level (career-oriented period). Therefore, some new subjects are introduced into Lower secondary education like Science and HistoryGeography. These changes more or less would puzzle teachers in doing their teaching after 2020.

Inquiry-based learning (IBL) has been gradually introduced into Vietnamese classes from the last curriculum innovation in 2002 to activate student learning. However, its implementation has been limited to changing learning environment, increasing students' interest and improving students' performance in teaching separate science subjects (Bui Thi Ngoc Linh, 2010; Mai Van Tien, 2014). Indeed, IBL has more values than those that teachers have exploited especially when teaching and learning are to develop student's competencies. These values will be elaborated in this paper.

\section{LITERATURE REVIEW \\ 2.1. Inquiry-based learning}

Inquiry-based learning has been developed as a pedagogical approach since the 1960s - during the discovery learning movement to promote students' activeness in learning. Its philosophy roots in constructivist learning theories with works of John Dewey (1938), Jean Piaget (1964) and Lev Vygotsky (1978). According to these authors, learning is understood as a process in which students actively use the cognitive skills and processes to construct knowledge for themselves when engaging in learning experiences and social interaction. However, different from other pedagogical approaches rooted in constructivist learning, IBL focuses on students' ability to pose research questions for the inquiry of new knowledge via "interacting with their learning environment, such as investigating, measuring, explaining, debating or doing experiment" (National Research Council, 1996, p.105).

The US National Research Council (NRC, 2000, p. 25) lists the characteristics of an inquiry-based classroom from the student's point of view as follows:

1) Focusing on investigating an open question or problem;

2) Giving priority to evidence-based reasoning; 
3) Answers must be grounded on evidence;

4) Comparing and contrasting one's answer with those of others to understand how they come to their conclusions; and

5) Discussing and adjusting one's answer.

The National Science Education Standards then adds the sixth characteristic of an inquiry-based classroom: students are those who design and conduct inquiry plans (NRC, 1996).

These features imply that IBL is to enable students to develop their knowledge and understanding of scientific ideas as well as scientific research methods. Students not only know what scientists think and do during inquiry process; but also understand how and why they think and do so.

\subsection{Levels of inquiry-based learning and instructional models}

Researchers and educators have identified a variety of models in which IBL can occur in different levels. Some of them are works of Heron (1971); Rezba, Auldridge, and Rhea [1999, cited in Bell, Smetana, \& Binns (2005)]; or Colburn (2000). In spite of using different criteria, these models include four levels of students' inquiry: (1) Students repeat the inquiry process by following provided research question, research procedure, and reaching conclusion; (2) Students are provided with research question and research procedure, and asked to find out conclusions; (3) Students are provided with research questions and asked to design their own research procedure and conclusion; and (4) Students are asked to pose their research questions, design procedure and find out answers. These levels reflect a fact that the less teachers intervene in student learning, the more opportunities student will have to construct their knowledge and understanding for themselves and the more independent they could become. In the highest level of inquiry and the ideal one also, students are able to self-direct their inquiry and learning process.

There are various instructional models which pursue to facilitate the implementation of IBL in schools, especially in learning and teaching Science. Some popular ones involve works of Hertbart (1901, cited in Bybee, Taylor, Gardner, Van Scotter, Powell, Westbrook \& Landes, 2006), Dewey (1933, 1938), Heiss, Obourn \& Hoffman (1953, cited in Bybee et al. 2006), and Bybee (1997, cited in Bybee et al., 2006; Duran \& Duran, 2004) and Eisenkraft (2003). Of these models, the 5E developed by R. Bybee - team leader of the Biological Science Curriculum Study seems to be the most popular and was developed from previous ones. Meanwhile, 7E model by Eisenkraft (2003) is an expanded version of $5 \mathrm{E}$ at phases 1, 4 and 5 (see Table 1 and 2).

Table 1. The 5Es Instructional model (R. Bybee et al., 2006, p.2)

\begin{tabular}{cl}
\hline Phase & \multicolumn{1}{c}{ Contents } \\
\hline Engage & $\begin{array}{l}\text { Teachers assess students' prior knowledge related to new knowledge content, identify their } \\
\text { misconceptions and engage them into new concepts through short learning activities, which aim } \\
\text { to promote their curiosity and elicit prior knowledge. At the end of this step, teachers should } \\
\text { facilitate students to raise their research questions or students will do it on their own. }\end{array}$ \\
\hline Explore & $\begin{array}{l}\text { Students engage in providing learning experience to investigate their questions. This experience } \\
\text { would ask them to bring their prior knowledge into play to form new ideas, predict likelihood, } \\
\text { design and conduct preliminary investigation. Via this phase, students may be able to identify } \\
\text { their misconceptions, construct new understanding and develop research skills. }\end{array}$ \\
\hline Explain & $\begin{array}{l}\text { Students transform results of inquiry which are abstract into verbal forms. They employ higher } \\
\text { order cognitive skills and processes, such as interpreting, justifying, and analysing information } \\
\text { and evidence to form their explanations. At the end of this phase, teachers could introduce new } \\
\text { concepts to help students develop an insight into these concepts. }\end{array}$ \\
\hline Elaborate & $\begin{array}{l}\text { Teachers challenge students with additional activities to reinforce students' new concepts and } \\
\text { link them with their prior knowledge. At the same time, students are asked to apply their new } \\
\text { knowledge and understanding into solving varying and new problems. }\end{array}$ \\
\hline Evaluate & $\begin{array}{l}\text { Teachers encourage students to self-assess their knowledge and skills. This is also the right time } \\
\text { for them to assess student's learning. Grounded on the feedback, teachers would make } \\
\text { adjustments and improve their teaching for the next lessons. }\end{array}$ \\
\hline
\end{tabular}


Table 2. The 5E \& 7E instructional models (Eisenkraft, 2003)

\begin{tabular}{ll}
\hline \multicolumn{1}{c}{ The 5E model } & \multicolumn{1}{c}{ The 7E model } \\
\hline \multirow{2}{*}{ Engage } & Elicit \\
\cline { 2 - 2 } Explore & Engage \\
\hline Explain & Explore \\
\hline Elaborate & Explain \\
\cline { 2 - 2 } & Elaborate \\
\cline { 2 - 2 } Evaluate & Evaluate \\
\hline
\end{tabular}

\subsection{Science and competency-based learning}

In spite of its long history in Western education, Science is quite new in Vietnam and will not be introduced to classes until the academic year of 2021-2022. It is the integration of knowledge from four separate disciplines of Physics, Chemistry, Biology and Earth Science. With this new subject, Vietnamese students would study fundamental facts, events, processes, and rules related to the existence and movement of the natural world.

In the context of the curriculum innovation, teaching and learning Science are to gain two goals: enabling students to (1) form and develop dispositions and general competencies and (2) develop Science competencies (MOET, 2018). General competencies involve autonomous learning and self-regulation, communication and collaboration, and problem solving and creative thinking. Science competencies comprise 3 components: scientific knowledge and understanding, scientific inquiry, and application. The first and third components are about employing cognitive skills to construct and elaborate knowledge. These cognitive skills could be lower order (remember and understand) or higher order (apply, analyse, evaluate and create) in the revised Bloom's taxonomy (Anderson et al., 2001). These components are underlined in the current curriculum.

The second component of scientific inquiry is original to Vietnamese teachers and learners. This competency includes scientific research skills and procedure (see Figure 1) by which students develop their knowledge and understanding via conducting investigation and/ or experiments. By developing their scientific inquiry, students would be able to develop their scientific thinking and research methods.

The shift from content-based into competency-based approach would result in changes in the objectives of teaching and learning Science. Teaching is not only to equip students with scientific knowledge and skills; more importantly, it is to develop students' general competencies and those in Science. Yet, this educational approach is new to teachers; so how could they accomplish their new teaching missions?

\section{METHODS AND RESULTS}

\subsection{Research methods}

This paper will analyse the requirements of Science teaching and learning after 2021 and identify a pedagogical approach that could enhance teachers' and students' success in the next curriculum innovation. Sticked with this purpose, the authors will analyse, synthesise and evaluate modern learning perspectives as well as IBL to gain an insight into this pedagogical approach. They then place IBL in the context of competency-based learning to examine whether this teaching approach could help teachers meet the new demands of teaching Science. Finally, the authors would propose some implications on teacher education and training to prepare teachers for IBL before the implementation of competency-based learning.

\subsection{Potential effects of inquiry-based learning on teaching and learning Science in Vietnam}

As a result of the authors' analysis, IBL comes to be a potential effective teaching approach to teach Science after 2021. Its 'effectiveness' could be seen from 4 features: (1) fostering authentic/ meaningful learning; (2) facilitating students' learning; (3) nurturing students' self-regulated learning; and (4) enhancing the development of general and Science competencies.

\subsubsection{Inquiry-based learning could foster authentic/ meaningful learning}

"Learning takes place through the active behaviour of the student; it is what he does that he learns, not what the teacher does" (Tyler, 1949, p.63).

As aforementioned, IBL focuses on providing students with learning experiences and engaging students into inquiry process. These experiences include observing or/ and conducting experiments in order to practise and develop students' ability to propose hypothesis, design experimental procedure, collect data, and analyse and explain the 
result. By actively engaging themselves in these activities, students have more opportunities to participate in both hands-on and minds-on activities.

Identify learning

problems/ pose

research questions
- Identify problems and pose questions;

- Analyse the context and identify learning problems
Make predictions and

propose hypotheses
- Analyse the problems in order to make predictions;

- Propose hypotheses;
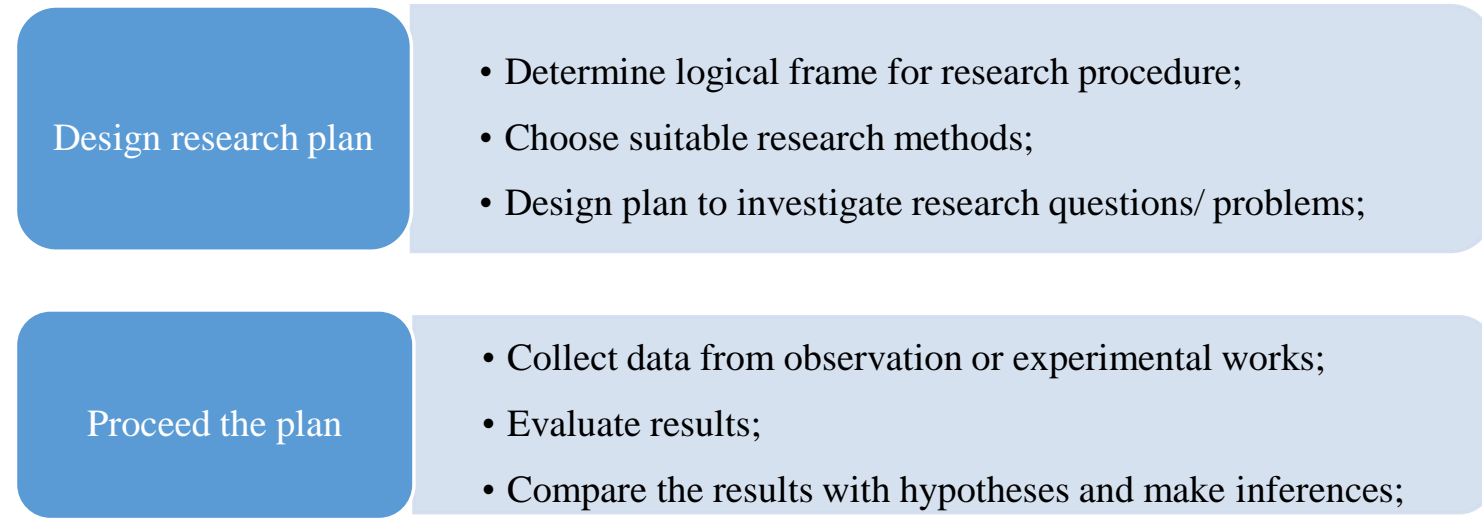

- Collect data from observation or experimental works;

- Evaluate results;

- Compare the results with hypotheses and make inferences;

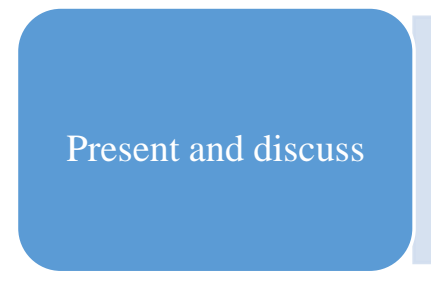

- Present results;

- Make a report;

- Exchange with friends and discuss the results with respect to other's ideas or perspectives;

\section{Make decisons and recommendations}

- Make decisions regarding solutions to the encountered problems.

Figure 1. The components of scientific inquiry (MOET, 2018)

Fredricks, Blumenfeld and Paris (2004) as reviewing studies on students' engagement, classifies it into three types: behavioural engagement (refers to students' conducting and participing in academic and non-academic activities), emotional engagement (involves students' affective reactions like love, boredom, persistence, enjoyment,...to their teachers, their peers, and their school as well as their sense of belonging and identification), and cognitive engagement (refers to students' efforts to employ cognitive repertoires to solve encountered problems - it is the combination of emotional and cognitive elements). Up to date, there are different views that emphasise on the significance of these different kinds of engagement. Tyler (1949) seems to pay more attention to emotional engagement since he believes that students' learning is enacted from their learning interests and needs. Meanwhile, Newmann and Marks (1996) emphasises cognitive engagement. Learning for them is to obtain academic 
achievements. Thus, it is crucial for students to invest their cognitive efforts in learning activities. Besides, he blames learning experience for merely involving students' behavioural engagement but not resulting in intellectual achievements which Prawat (1992) names "naïve constructivism" - learning that over-emphasises on activities but not the meaning made from activities. Stated differently, meaningful learning occurs when students interact with their environment and use their cognitive skills to make sense of their learning experiences (Powel \& Kalina, 2009).

In IBL, three types of students' engagement are emphasized, which is clear with the 5E instructional model presented in Table 1. Emotional engagement is prioritised at the beginning of the inquiry process: teachers use different activities to promote students' curiosity and interest. The more these activities reflect problems in the real life and close to their Zone of proximal development (Vygotsky, 1978), the more interested and motivated students could be. This is also the factor that influences students' cognitive and behaviour engagement in phase 2, 3 and 4 when all students are expected to actively participate in observations, laboratory works to construct or expand new knowledge.

\subsubsection{Inquiry-based learning could facilitate students' understanding}

'Understanding' is not simple as students can explain or present ideas and concepts in various forms (Anderson et al., 2001), Wiggin and McTighe (2005, p.85-103) clarify that understanding has six facets:

i. Explanation: Understanding relates that students know exactly what they have learnt by explaining about their learning and giving the reasons to support it. These explanations need to be generated in a thoughtful manner to connect ideas to the big ideas and to justify these connections.

ii. Interpretation: It is essential that if one understands what they have learnt, they are able to make sense of their learning.

iii. Application: Students are capable of transferring their knowledge into new situations to get new knowledge and reach new level of understanding, especially in unfamiliar and realistic settings. This practice would enhance their intellectual power to cope with diverse problems in their lives and easily transfer their knowledge into practice.

$i v$. Perspective: Understanding means that taken for granted assumptions, conclusions and implications need to be identified and removed as solving problems. Currently, a critical and insightful view should be employed. In addition, students need to acknowledge that each person comes up with their own perspectives towards a question or problem. These perspectives can be quite different but all may be plausible to solve the problem or answer the question.

v. Empathy: While understanding emphasizes on critical perspective that one holds, it is crucial for her/ him to be tolerant with other perspectives which he tends to label as "odd" or "alien" points of view. (S)he needs to detach from her/ his view to see the reasonable and meaningful alternatives. On so doing, students can solve the problem or answer questions from different perspectives which in turn enables them to be open-minded and become mature in their thinking.

vi. Self-knowledge: Understanding involves knowledge about one's self to help students self-regulate and selfassess their learning process and performance. It also relates to self-reflection and the evaluation of this reflection.

From this view, understanding is not limited to developing students' knowledge and their application skills; it also means developing students' perspectives, thinking dispositions and meta-cognition.

With its characteristics, IBL absolutely could enhance students' understanding. The ability to interpret and explain would be developed as students explain the relationship between hypotheses and results; explain the meaning of each step in the research plan; interpret results gained from laboratory works; explain the linkage between priority and what they observe to come to their final explanations. Meanwhile, students would practise their application skills at the end of inquiry process elaborated in phase 3 of the $5 \mathrm{E}$ model and also an indispensable phase of any teaching process.

Enabling students to have their own perspective and cognitive empathy can be done if teachers organise students to exchange and discuss their ideas or perspectives (phase 3 in the $5 \mathrm{E}$ model). These activities would let students know that there may be more than one solution to a problem and help them to become more open to ideas that are different from theirs. In terms of developing students' self-knowledge, the phase of evaluation is the ideal time to do. Teachers should require students to ask themselves questions like 'Do I collaborate well with my friends? Is my research plan reasonable? Why? What cognitive skills and process enable me to solve my problems? Is there anything I need to improve regarding my problem solving skills?...' As students answer these questions, they would gain more understanding about themselves. 


\subsubsection{Inquiry-based learning could nurture students' self-regulated learning}

Learning is impacted by both internal and external resources. The internal resource means students' cognition while the external resource encompasses the learning goals, materials, supports and learning environment in which students carry on their learning (Garrison, 1992). If students take full responsibility to build up knowledge for themselves and take control over their learning, they are self-directed (Zimmerman, 1990). Put differently, selfdirected learning is that students intentionally employ their cognitive repertoires to develop their knowledge capital and make decisions on their learning goals and activities (Zimmerman, 1990). Students' responsibility to learn and their control over learning are interrelated and impact each other. Students' responsibility will increase according to the increase in the level of their learning control. Conversely, the increase in students' control enhances the possibility to achieve their desired outcomes and thus motivates their self-directed learning (Garrison, 1992).

Inquiry-based learning, with its characteristics and the levels it can occur, would be able to boost students' selfdirection. The hierarchy of inquiry activities in aforementioned models (Colburn, 2000; Heron, 1971; Rezba et al., 1999) allows teachers to scaffold students' self-regulated learning by gradually decreasing their intervention while increasing students' control over their learning (Garrison, 1992). The below example of four levels of IBL created by Rezba et al. (1999, cited in Bell et al., 2005) reflects this potential of the recommended pedagogical approach (see Table 3). It is clear that from the low level to the high level of inquiry, students' learning responsibility and their control over learning gradually increase. Meanwhile, teachers from the 'sage on the stage' has changed into the 'guide on the side'.

Nevertheless, it is not easy for teachers to facilitate students' self-direction. They need to know the right time to give back control to their students and when they should go back to help them not to go too far away from their learning goals. More importantly, teachers need to be capable of designing teaching strategies that benefit students in setting up learning goals, choosing learning tasks, designing learning activities, seeking supports from teachers as well as developing cognitive and meta-cognitive processes (Garrison \& Archer, 2000).

Table 3. Levels of inquiry in an effervescent antacid tablet activity (as cited in Bell et al., 2005)

\begin{tabular}{|c|c|c|}
\hline Inquiry levels & Description & Examples \\
\hline Confirmation & $\begin{array}{l}\text { Students confirm a principle } \\
\text { through an activity in which the } \\
\text { results are known in advance. }\end{array}$ & $\begin{array}{l}\text { "In this investigation, you will confirm that the rate } \\
\text { of a chemical reaction increases as the temperature } \\
\text { of the reacting materials increases. You will use } \\
\text { effervescent antacid tablets to verify this principle. } \\
\text { Using the following procedure, record the results as } \\
\text { indicated and answer the questions at the end of the } \\
\text { activity". }\end{array}$ \\
\hline Structured inquiry & $\begin{array}{l}\text { Students investigate a teacher- } \\
\text { presented question through a } \\
\text { prescribed procedure. }\end{array}$ & $\begin{array}{l}\text { "In this investigation, you will determine the } \\
\text { relationship between temperature and the reaction } \\
\text { rate of effervescent antacid tablets and water. You } \\
\text { will use effervescent antacid tablets and water of } \\
\text { varying temperatures. Using the following } \\
\text { procedure, record the results as indicated and } \\
\text { answer the questions at the end of the activity." }\end{array}$ \\
\hline Guided inquiry & $\begin{array}{l}\text { Students investigate a teacher- } \\
\text { presented question using student } \\
\text { designed/selected procedures. }\end{array}$ & $\begin{array}{l}\text { "Design an investigation to answer the question: } \\
\text { What effect will water temperature have on the rate } \\
\text { at which an effervescent antacid tablet will react? } \\
\text { Develop each component of the investigation } \\
\text { including a hypothesis, procedures, data analysis, } \\
\text { and conclusions. Implement your procedure } \\
\text { only when it has been approved by your teacher." }\end{array}$ \\
\hline Open inquiry & $\begin{array}{l}\text { Students investigate topic-related } \\
\text { questions that are student } \\
\text { formulated through student } \\
\text { designed/ selected procedures. }\end{array}$ & $\begin{array}{l}\text { "Design an investigation to explore and research a } \\
\text { chemistry topic related to the concepts we have been } \\
\text { studying during the current unit on chemical } \\
\text { reactions. Implement your procedure only when it } \\
\text { has been approved by your teacher." }\end{array}$ \\
\hline
\end{tabular}




\subsubsection{Inquiry-based learning could foster the development of students' competencies}

As analysed in the last three sections, IBL has the potential to be an effective pedagogical approach in teaching Science in terms of developing students' general and Science competencies. The six facets of 'understanding' would put the foundation for students to develop their problems solving, critical thinking, creative thinking and metacognition. Self-regulated learning that can be developed among students would enable them to meet new demands of the innovative curriculum. The opportunities that IBL could provide students to engage in true learning experience including that of group working would be the effective conditions for students to hone their communication and collaboration.

Additionally, IBL is an umbrella theme under which it involves problem-based learning and project-based learning (Dobber, Zwart, Tanis \& van Oers, 2017). This feature would give teachers more options in organising diverse learning activities to develop students' competencies. The cognitive and meta-cognitive skills and processes, their cognitive empathy that students could develop during their learning with IBL once again reinforce the development of required general competencies. Furthermore, IBL emphasises experimental works to enable students' investigation of their research questions/ problems. Hence, students could improve their scientific research methods and procedure which in turn strengthen their science competencies.

\section{DISCUSSION AND CONCLUSION}

Inquiry-based learning could be an effective pedagogical approach in teaching Science regarding developing students' competencies if it is implemented appropriately. It could not only enhance meaningful learning, foster students' understanding and nurture their self-regulate but also facilitate them to develop required general and Science competencies. Inquiry-based learning yet seems to be difficult for teachers to successfully implement IBL since it requires them more pedagogical knowledge and skills. Admittedly, it is crucial to prepare teachers (both preservice and in-service ones) for the implementation of the innovative curriculum and IBL.

Pre-service and in-service teachers need guides to implement IBL. They may need to know instructional techniques and strategies in choosing learning topics and related learning tasks, designing learning activities that meet students' learning needs and interests. Also, IBL requires teachers to share their control over learning with their students. Therefore, it needs to inform pre-service and in-service teachers factors that they could use to determine the levels of control they could share and when they should go back.

Some research indicates that one of the factors contributing to the failure of implementing active teaching and learning in Vietnam is that teachers fail to trust in students' capacity to learn in new ways (Pham Thi Thanh Huong, 2011; Bui Thi Ngoc Linh, 2019). It is necessary to provide teachers with results of successful implementation of IBL from empirical studies and evidence from Neuroscience to let them know that if students receive sufficient support from their teachers with appropriate instructions, they are absolutely capable of learning in new ways including IBL. Universities/ schools/departments of education should also pay more attention to teaching practicum, microteaching or practical activities regarding teaching in order to provide pre-service teachers more opportunities to practice their pedagogical skills and increase their confidence in teaching.

\section{REFERENCES}

Alan Colburn (2000). Inquiry primer. Science scope journal, 23(6), 42-44.

Anderson, L. W., Krathwohl, D. R., Airasian, P. W., Cruikshank, K. A., Mayer, R. E., Pintrich, P. R.,... Wittrock, M. C (2001). A taxonomy for learning, teaching, and assessing - A revision of Bloom's taxonomy of educational objectives. New York: Addison Wesley Longman.

Bell, R. L., Smetana, L., \& Binns, I. (2005). Simplifying inquiry instruction. The Science Teacher, 72(7), 30-33.

Bui Thi Ngoc Linh (2010). Applying Inquiry-based learning into teaching Chapter Reproduction - Biology 11. Master thesis at Hanoi National University of Education, Vietnam.

Bui Thi Ngoc Linh (2019). Perceptions of Vietnamese teachers towards incorporating dialectical thinking: A transformational model of curriculum and pedagogy. Doctoral thesis at University of Newcastle, NSW, Australia. 
Bybee, R. W., Taylor, J. A., Gardner, A., Van Scotter, P., Powell, J. C., Westbrook, A., \& Landes, N. (2006). The BSCS 5E instructional model: Origins and effectiveness. Colorado Springs, CO80918.

Colburn, A. (2000). An inquiry primer. Science scope, 23(6), 42-44.

Dewey, J. (1933). How we think: A restatement of the relation of reflective thinking to the educative process. Lexington, MA: D.C Heath and Company.

Dewey, J. (1938). Experience and education. New York: Kappa Delta Pi/Touchstone.

Dobber, M., Zwart, R., Tanis, M., \& van Oers, B. (2017). Literature review: The role of the teacher in inquiry-based education. Educational Research Review, 22, 194-214.

Duran, L. B., \& Duran, E. (2004). The 5E Instructional Model: A Learning Cycle Approach for Inquiry-Based Science Teaching. Science Education Review, 3(2), 49-58.

Eisenkraft, A. (2003). Expanding the 5E model. Science Teacher, 70(6), 56-59.

Fredricks, J. A., Blumenfeld, P. C., \& Paris, A. H. (2004). School engagement: Potential of the concept, state of the evidence. Review of educational research, 74(1), 59-109.

Garrison, D. R. (1992). Critical thinking and self-directed learning in adult education: Ananalysis of responsibility and control issues. Adult Education Quarterly, 42(3), 136-148.

Garrison, D. R., \& Archer, W. (2000). A transactional perspective on teaching and learning: A framework for adult and higher education. Advances in learning and instruction series. Elsevier Science, Ltd, Oxford, UK.

Mai Van Tien (2014). Applying Inquiry-based learning into teaching Chapter Particle Dynamics - Physics 10. Master thesis at VNU University of Education, Vietnam.

MOET (2018). Innovative curriculum for General Education. Retrieved from http://rgep.moet.gov.vn/chuong-trinhgdpt-moi/Pages/du-thao-ct-tong-the.aspx?ItemID=4728

Newmann, F. M., \& Marks, H. M. (1996). Authentic pedagogy and student performance. American Journal of Education, 104(4), 280-312.

NRC (1996). National Science Education Standards. Washington, DC: The National Academies Press.

NRC (2000). Inquiry and the National Science Education Standards. Washington, DC: The National Academies Press.

Pham Thi Thanh Huong (2011). An investigation of perceptions of Vietnamese teachers and students toward Cooperative Learning (CL). International Education Studies, 4(1), 3-12.

Piaget, J. (1964). Part I: Cognitive development in children: Piaget development and learning. Journal of Research in Science Teaching, 2(3), 176-186.

Powell, K. C. \& Kalina, C. J. (2009). Cognitive and social constructivism: Developing tools for an effective classroom. Education, 130(2), 241-251.

Prawat, R. S. (1992). Teachers' beliefs about teaching and learning: A constructivist perspective. American journal of education, 100(3), 354-395.

Tyler, R. W. (1949). Basic principles of curriculum and instruction. Chicago: The University of Chicago Press.

Vygotsky, L. (1978). Mind in Society. The Development of Higher Psychological Processes (M. Cole, V. JohnSteiner, S. Scribner \& E. Souberman, Eds.). Cambridge, Massachusetts: Harvard University Press.

Wiggins, G. P., \& McTighe, J. (2005). Understanding by design (2 $2^{\text {nd }}$ ed.). Pearson Education, Inc.

Zimmerman, B. J. (1990). Self-regulated learning and academic achievement: An overview. Educational Psychologist, 25(1), 3-17. 